\title{
Uncovering Desire: Explorations in Eros, Aggression and the Question of Theosis in Marriage
}

\author{
Pia Chaudhari
}

\section{INTRODUCTION}

Over 1500 years ago, in Antioch, St. John Chrysostom gave advice to men seeking to pacify an upset wife. Speak lovingly to her, he instructed; tell her "that you love her more than your own life... and that your only hope is that the two of you pass through this life in such a way that in the world to come you will be united in perfect love." Say to her "Our time here is brief, and fleeting, but if we are pleasing to God, we can exchange this life for the Kingdom to come. Then we will be perfectly one both with Christ and each other and our pleasure will know no bounds ${ }^{1}$."

This counsel is striking in the depth and weight he gives to the love, and pleasure in such love, between a husband and wife. Notably, this love does not end with death but transcends it, extending into the Kingdom of Heaven. Elsewhere he speaks warmly of the same bond, saying "the power of this love is truly stronger than any passion; other desires may be strong but this one alone never fades. This love (eros) is deeply planted within our inmost being." ${ }^{2}$

We have here a strong and simple insight into the nature of love as eros. It is deeply implanted in our inmost beings, and it is stronger than death. How, then, does it relate to salvation? Does it provide a clue as to the link between our embodied lives now and the life to come? And what do we do with aggression that surfaces, or goes underground, to bedevil the best of our attempts at union? This paper is a brief exploration of the intertwining of eros and theosis in the sacramental union that is marriage, using depth psychological insights and Orthodox theology. It is an attempt to uncover the generative energy of desire, what Olivier Clement has likened to the psychoanalytic concept of $l i b i d o^{3}$, and perhaps further texture the discussion of the role of desire in salvation.

1 St. John Chrysostom, On Marriage \& Family Life, Homily 20, trans. Roth, C.P., \& Anderson, D., St Vladimir's Seminary Press, 1986, 61.

2 Ibid., 44.

3 Clement, O., The Roots of Christian Mysticism, (New York: New City Press, 1993),134. 


\section{The 'False Self'}

I will start by taking what might seem to be a detour, to highlight a small but profound work by Fr. Vasileos Thermos, titled In Search of the Person. In this work, Fr. Thermos, an Orthodox priest and psychiatrist, discusses parallels between the seminal theories of Donald Winnicott, a British psychoanalyst, and the treatises of St. Gregory Palamas. It is a defense of the roles of the body, emotions, and desire in the spiritual life. He describes Winnicott's theory of the "false self," a self which is constructed in response to environmental wounding or deprivation, and which appears to live but which actually lacks "tissue aliveness," being capable neither of spontaneity nor full-bodied relationship with others or life itself. He then turns to St. Gregory to emphasize that the mortification of body, emotions, and desires is not the proper course of asceticism. He clarifies that the ascetic path is designed to transform desire, not eradicate it. Using both Winnicott and Palamas, he shows that the mortification of desire through repression or dissociation only cripples our ability to desire anything, including God. The deception, however, is that the false self can appear to be highly religious. According to Thermos, the false self "moves on the 'level of 'exactness' and with a fixation on 'purity.' For this reason it isolates the only 'pure' thing which it believes itself to possess, the intellect which it controls, and offers it to God, thereby implying that the body, feelings and desires are 'children of a lesser god.' One is left wondering if the Incarnation of the Logos has been comprehended and experienced."4

Because the false self is itself a construct, it can only find resonance in religious constructs, not in existence itself. This leads to a primacy of disembodied spirituality: "The theological foundation of the false self comprises an essentially bodiless existence as the zenith of self-sufficiency which flirts with the idea that one is equal to God." ${ }^{5}$ For Thermos, the emphasis on becoming a person, reminiscent of other Orthodox theologians such as Olivier Clement and John Zizioulas, is integral in the journey of theosis. One might say we are called to become more human, not less, in our journey towards "becoming God." This entails a life of emotions, feelings and desire fully lived. Thermos writes: "Because He [God] is the source of feeling and desiring, He calls man [or woman] to personal communion by raising him [or her] to the level of a person who feels and desires. Through this personal calling, man [or woman] is made able to feel and desire; because He is the truth, man [or woman] can become true and encounter the actual person who is the source of his [or her] person and learn to commune."6 (italics mine)

\footnotetext{
4 Thermos, V. In Search of the Person; True and False Self According to Donald Winnicott and St. Gregory Palamas,"(Montreal: Alexander Press, 2002). Interestingly, Thermos also notes here, drawing on Winnicott as well, that "in the great majority of cases the depreciation of the body in men is connected with the depreciation or even fear of women, since women remind them of their bodily drives." 51.

5 Ibid., 61.

$6 \quad$ Ibid., 67.
} 
We have here another strong insight. True self life, embodied life, is also necessarily life lived in relationship, in communion. It is personal relatedness that calls forth the true self. How then, does marital life explore and expand on the boundaries of holiness, if holiness is defined by Olivier Clement in saying "....holiness is life in its fullness. And there is holiness in each human being who participates vigorously in life. There is holiness not only in the great ascetic but in the creator of beauty, in the seeker after truth who heeds the mystery of creation....in the deep love between a man and a woman...."7

\section{Marriage as SaCrament}

The Orthodox marriage is sacramental. As Orthodox theologian John McGuckin writes: “...many Orthodox theologians have linked the couple’s journey towards union in flesh and spirit, with a trope of the perichoresis of the Persons of the Holy Trinity, radiating out essential unity in their harmony. The Trinity itself, the goal of all Christian life, is the pattern and aspiration of the mystical unity that the marriage can bear witness to. Such a mystery of union is only possible because of the indwelling Trinity." Such a marriage requires ascesis of both partners, hence the Orthodox understanding of the martyrdom of marriage, where in putting on the mind of Christ, the phronema Christou, each partner submits to the willingness to accept the death of self for the sake of the loved one.? The ascetic struggle McGuckin outlines is the "constant struggle to make all things in a Christian life charged with light and graciousness, not least the powerful forces of the desire for acquisition and the desires of the flesh... But the Gospel....does not presume that one should be devoid of desire: it is the use to which the fundamental drives of human energy are placed that is in question." 10

We see here a return to the power of desire, properly transformed, as an active driver in the sacrament of marriage. In this context, sexuality itself is transformed: "The sacred mystery of Christian marriage sings a different song to the anxious (and often violent) subtext of sexuality as the world knows it. The key issue, of course, is the presence of joy... [without] this renovatory 'mind of Christ' at the core of a Christian marriage, the very concept of two human beings staying with one another for decades would be unimaginably boring and suffocating. With it, the love deepens day by day, for those who have the eyes to see, and reveals new layers of the significance of being." 11

To avoid the pitfall of "false self" religiosity, a confusion of the phronema Christou with a life of stultifying "shoulds," this radiant conceptualization must also be grounded in the life of the body, in the emotions and desires. Yet, is it not

$7 \quad$ Clement, Christian Mysticism, 265.

$8 \quad$ McGuckin, J.A., The Orthodox Church, (London: Wiley-Blackwell, 2011), 314.

9 Ibid., 319.

$10 \quad$ McGuckin, The Orthodox Church, 315.

11 Ibid., 317. 
here that we risk a marriage of what Orthodox theologian John Behr has called a "companionate" or "unitive" marriage, one that is self-centered, rather than a marriage with Christ at the center? ${ }^{12}$ The tension of embracing desire becomes a question of discernment as to when desire is "disordered," to use the language of the Fathers, and the work of uncovering and living from God-given desire. If we look to marriage from another angle, I believe we can see more concretely how this may happen, how eros does not lead to fusion, nor true desire to self-gratification. On the contrary, I would argue that eros can only truly thrive in differentiation, thus allowing for relatedness, and desire is the deep reaching out from self to "Other," which actually bespeaks the end of pathological narcissism or religious solipsism.

\section{Marriage as Conjunction of Opposites}

Jungian psychoanalyst and noted theological scholar Ann Belford Ulanov writes about marriage from a depth psychological perspective, putting the alchemical notion of "coniunctio," the conjunction of opposites, at the center, and using object-relations theory to elucidate the kinds of interactions that take place between the couple: "The coniunctio archetype [in marriage]....[brings] the interpenetration, differentiation, and integration of elements in each person's psyche [to] be worked on, as well as the meeting and matching and mating of all these elements between them. Such a joining is intimate at a very deep level, causing radical intrapsychic changes as well as changes in the most habitual behavior." ${ }^{13}$

For Ulanov, such a marriage does not avoid conflict, but utilizes areas of tension to press through to the deeper issues that each partner is called to work on. She uses Jungian language of the 'Self', representing the whole psyche of each person-conscious and unconscious, as well as something more that gives access to a sense of God-to ask what is the "Self" engineering in each person. One could also ask, using McGuckin's language, to "what new depths of being" is each person being called

Both partners commit to engaging in "the work of love" which she describes as "making space for its own flowing from surface to depths, from each to other and back again, planting the world, making it bloom, building a bridge that extends beyond the grave."14 (italics mine). The hard work of differentiating and consciously relating to what she calls "contaminating elements" rather than repressing them or identifying with them (both of which could be likened to distortions of the passions), yields the reward of "a union of the different elements within each person as well as a union between them that supports each in being entirely his or her own true self." ${ }^{\prime 1}$ Aliveness floods in.

\footnotetext{
12 Behr, J., "Marriage and Asceticism," Sobornost 29:2 (2007), 24-50, 24 \& 49.

13 Ulanov, A.B., "Coniunctio and Marriage," in The Spiritual Aspects of Clinical Work,

(Einsiedeln: Daimon Verlag, 2004), 132.

14 Ibid., 136.

15 Ibid., 137.
} 
Such a union, she writes, "makes for fission, not fusion, for fire, not boredom....neither is allowed to clamp down on personal impulse for the sake of compromise with reality demands to the point where they lose access to the creative imagination in their marriage. Both seek the alive and real in themselves and in each other... [such a couple is] a small example of how to be passionate and alive in a permanent relationship, imaginatively making the world." ${ }^{16}$

\section{Transformation of Aggression}

Paradoxically, this process of full commitment to engaging with self and other leads to a progressive purging of the ego of possessive and power motives. Each has to learn to give up "sadistic gratification," "fighting dirty," in order to harness the tremendous energy and aggression underlying these actions and put it to different use. The concept of aggression here is not used in the colloquial sense, but rather to denote a kind of primal energy which is morally neutral, in much the same way some of the Fathers described the inherent neutrality of the passions, while being keenly aware of the possibility of their misuse. ${ }^{17}$ She writes: "We need aggression to focus on the true worth of the other, to dig it out, and to work to restore it, and to differentiate that effort from trying to impose our image on the other... a transcendent presence lives in the other.... [who is] made in the image of God...we dig down to it and excavate it... the support must be vigorous, summoning, lavish, and aimed right at the center of the other person's existence the way the other is connected to all existence. Betrayals in marriage usually issue from betrayal of this deeper center."(italics mine) ${ }^{18}$ This is the opposite of a desire that uses the other as a "self-object," or subjective-object, but is a desire that recognizes the other as subject in their own right. As Clement reminds us "...we perceive in [the other] an irreducible personal existence, beyond limitations and errors, beyond even the disappointment we may have felt for the moment. The other is in the image of God, not of us." ${ }^{19}$ (italics mine)

\section{'Ruthlessness', Revelation of the Other, and the End of the “False Self”}

In such a marriage, two extraordinary healings can take place. Aggression, so often feared as destructive, can become "the means through which we secure the energy of living support," ${ }^{20}$ and is repaired as it is used to explore and unearth and sustain the best in the other. It is, of course, still painful to fight, but the

$\begin{array}{ll}16 & \text { Ibid., } 139 . \\ 17 & \text { Cf, for example. St. Maximus, 'On the Utility of the Passions.' } \\ 18 & \text { Ulanov, Coniuncto and Marriage, } 141 . \\ 19 & \text { Clement, Christian Mysticism, } 279 . \\ 20 & \text { Ulanov, Coniuncto and Marriage, } 142 .\end{array}$


fighting can be ultimately constructive, rather than destructive. She writes "we know now that aggression can serve love as well as destroy it." 21

The other area of healing lies through the experience of what psychoanalyst Winnicott termed "ruthlessness." ${ }^{22}$ Like aggression, this is a word that colloquially has negative connotations, but which in the depth psychological world is descriptive rather than pejorative. It describes the direct movement of going towards an object of desire. It does not fear one's own force of being; it trusts the other to survive the full on engagement with one's own energy. At an unconscious level, something astonishing happens, which is that when we do not seek "to control through projected images of who we want the other to be, or fear the other might be, or need the other to be, or think the other needs us to be. We let be. And we discover, uncover, greet the one who is left after our projections have been destroyed....this may happen when the other disappoints us: he or she failed to live up to our idealized image and the image is destroyed. Thereby we release ourselves and the other to find out who is actually there. If we are using our aggression to reach the best self of the other, this is all gain, no loss...we may have lost a fantasy but we have gained a reality with which to interact and in which to unfold our own self." 23

St. Maximus the Confessor wrote: "The aim of faith is the true revelation of its object. And the true revelation of faith's object is ineffable communion, with him, and this communion is the return of believers to their beginning as much as to their end... and therefore the satisfaction of desire." ${ }^{24}$

The true revelation of the object, if we are to learn that it exists as subject in its own right, outside our unconscious fantasies of omnipotence, requires that we live ruthlessly-not in the colloquial sense of the term-but in the sense of going all out in our movements towards the other, not withholding our being. We learn to survive the destruction of our fantasies because in exchange for fantasy we encounter the reality of an "Other" with whom we can have a real relationship. Thus, I would argue that while a conscious fear of desire can stem from the awareness that desire distorted turns to lust and acquisitiveness, a fear which nestles neatly with the sincere attempt at "moral living," the deeper unconscious fear of desire is the fear of the end of narcissism, omnipotence, or what theologically could be termed as selfidolatry. Genuine desire drives us out of ourselves towards the other, and any such encounter with a real Other must mean the experiential end of our illusions that we stand at the center of the universe, inviolate and invulnerable-indeed, immortal. It is the end of the false self. To encounter Otherness is to encounter our own limits, but it is also to encounter the possibility of true love between two who are other to each other and yet connected through the power of eros, living out of desire.

$21 \quad$ Ibid., 142.

22 Ibid., 143.

23 Ibid., 145.

24 Clement, Christian Mysticism, 266. 


\section{Marriage AND Theosis}

For St. Maximus, the process of theosis is the union through desire with God, and the increasing identification with God through sharing in the life of God. Marriage is not the same process, yet the schooling of eros, aggression, and ruthlessness in pursuit of love may uncover desire in us in such a way that personal communion with God becomes deeper as does communion with husband or wife.

Purging the relationship of "contaminating energies" requires self-examination, and would be strengthened by repentance, confession, and healing; Sacraments in the Church, and processes also deeply known to depth psychology. The circling of the relationship around the larger questions of "what is the Self engineering" creates a conscious awareness of both immanent and transcendent energy in which the couple shares. It is a central locus of conscious engagement and hard work, driven by love and desire, that will demand the death of the narcissistic false self, and endlessly reveal new levels of true life. Held within the genuine desire to grow in the phronema Christou, and participation in the ever unfolding life of the Trinity, such an understanding can allow the totality of each person to be brought into the marital union, not just their personas or the parts deemed acceptable by the other. Could not such a marriage, with Christ in its midst, become a microcosm of the maxim of salvation of the Fathers: "that which is not assumed is not healed"?

This is no longer a false self religiosity where the collective 'superego' is placed at the center (or conflicting superegos fought over), but rather a shared devotion to the Living God, who calls us forth in unexpected ways, heralds the new, and brings life where there was death. Deification is not the annihilation of human interaction, but its deepening. As Clement elucidates: "To be deified is therefore to become someone living with a life stronger than death, since the Word is life itself and the Spirit is the one who brings life. All human possibilities are brought into play. The structures of thought, feeling, friendship, creativity, while remaining only human structures, receive an infinite capacity for light and joy and love." 25

Such a marriage, Ulanov writes, "[pulls] the world in and pull[s] the two persons into the world. Why this is so has to do with the center that goes on being constructed. That core of freedom keeps producing new forms of itself that insist on going out to others and pulling others into it...This is the greater conjunctio, that does not breakdown but breaks through the bounds of our ordinary perceiving in time and space to the presence of the beyond. The cause and effect of the conjunction of opposites is love, a love in time and outside of time... To be aware of this dimension is directly to participate in mystery..." 26

This understanding of the embodied relationship between two people, circling around the transcendent and taken up into it, without losing its own particularity, is echoed in the resurrection theology of Clement. He writes: "Resurrection begins already here below. For the early Church a deeply spiritual man [or woman] 
is one is already "risen again." The truest moments of our lives, those lived in the invisible, have a resurrection flavor. Resurrection begins every time that a person, breaking free from conditionings, transfigures them... Resurrection begins every time that a person plunges this world's opaque, divisive, death-riddled modality into its Christ-centered modality, into that 'ineffable and marvelous fire hidden in the essence of things, as in the Burning Bush." ${ }^{27}$ (italics mine)

Paradoxically, it becomes clear that we need to live in and through our bodies, feelings and emotions in order to reach to that which transcends our bodies and transforms our desiring. The eros spoken of by St. John Chrysostom builds a bridge from this life to the next, from body instinct to spirit. We have to dig down in order to see the heavens more clearly. We have to grab hold of our aggression and ruthless energies in order to perceive the other more truly and to love more deeply. Orthodox tradition, theology, and wisdom, and the insights of depth psychology, illuminate the enormous healing possibilities contained within the sacrament of marriage; the possibilities to transform aggression, break through narcissistic fantasies of omnipotence, and to uncover desire in order to unleash love-love for God, for each other, and for life. 